\title{
Deionizer Device
}

National Cancer Institute

\section{Source}

National Cancer Institute. Deionizer Device. NCI Thesaurus. Code C50353.

A device designed to remove ions from a substance or environment. 